JIPFRI, Vol. 4 No. 2

Halaman: 56 - 64

November 2020
JIPFRI (Jurnal Inovasi Pendidikan Fisika dan Riset IImiah)

https://doi.org/10.30599/jipfri.v4i2.728

\title{
Pembuatan Sistem Perancang Peredam Kebisingan
}

\author{
Rahmat Bagus Prasetya ${ }^{1 *}$, Sunartoto Gunadi ${ }^{2}$, dan Erna Kusuma Wati ${ }^{3}$ \\ 1,2,3 Program Studi Teknik Fisika, Fakultas Teknik dan Sains, Universitas Nasional \\ Jalan Sawo Manila, Pasar Minggu, Jakarta 12520 \\ *E-mail: rahmatbagusprasetya@gmail.com
}

\begin{abstract}
Abstrak
Salah satu masalah yang dialami oleh masyarakat baik itu di rumah ataupun di tempat kerja adalah terganggunya rasa konsentrasi serta kenyamanan yang disebabkan oleh adanya kebisingan. Penelitian ini bertujuan untuk mengukur kebisingan sekaligus memberikan material untuk mengurangi kebisingan di area tersebut. Waktu pengambilan data adalah satu hari dilakukan selama 4 kali sampel pengambilan data berdasarkan rujukan dari Kementrian Lingkungan Hidup, no : Kep-48/MENLH/11/1996. Metode pengukuran juga menggunakan standar SNI nomor 7231 tahun 2009. Kemudian berdasarkan nilai kebisingan yang tampil pada alat akan langsung diberikan rekomendasi material berdasarkan nilai Noise Reduction Coefficient (NRC), Sound Transmission Coefficient (STC) dan Loss Factor. Hasil pengukuran kebisingan di Masjid AT-Taqwa sebesar 77,1 dB dan rekomendasi material yang disarankan oleh alat adalah Acourete Perfowood - Acoustic Panel 881 dengan NRC 0,375 . Sedangkan pengukuran di musholla stasiun Pasar Minggu sebesar 76,8 dB dan rekomendasi material yang disarankan oleh alat adalah Accourete Fiber 300 dengan NRC 0,44.
\end{abstract}

Kata kunci: Kebisingan, dBA, NRC, STC, Loss Factor, Material Bising.

\begin{abstract}
One of the problems experienced by the community, whether at home or at work, was the disruption in the sense of concentration caused by noise. This study aims to measure noise as well as provide materials to reduce noise in the area. The time for data collection was one day, carried out for 4 samples of data collection based on a reference from the Ministry of Environment, no: Kep-48 / MENLH / 11/1996. The measurement method also using SNI standard number 7231 in 2009. Then based on the noise value displayed on the instrument, material recommendations will be given based on the value of Noise Reduction Coefficient (NRC), Sound Transmission Coefficient (STC) and Loss Factor. The results of noise measurements at the AT-Taqwa Mosque are $77.1 \mathrm{~dB}$ and the recommended material recommended by the tool is Acourete Perfowood - Acoustic Panel 881 with NRC 0.375. While the measurement at the Musholla at Pasar Minggu station is $76.8 \mathrm{~dB}$ and the recommended material recommended by the tool is Accourete Fiber 300 with an NRC of 0.44 .
\end{abstract}

Keywords: Noise, dBA, NRC, STC, Loss Factor, Noise Material.

\section{PENDAHULUAN}

Salah satu masalah yang sering dialami oleh masyarakat baik itu di rumah ataupun di tempat kerja adalah terganggunya rasa konsentrasi serta kenyamanan yang disebabkan oleh adanya kebisingan. Kebisingan adalah bunyi yang tidak diinginkan dari usaha atau kegiatan dalam tingkat dan waktu tertentu yang dapat menimbulkan gangguan kesehatan manusia dan kenyamanan lingkungan.

Kemudian kebisingan merupakan salah satu faktor bahaya fisik yang sering dijumpai di lingkungan kerja (Fithri \& Annisa, 2015). Umumnya sumber kebisingan dapat berasal dari kegiatan industri, perdagangan, pembangunan, alat pembangkit tenaga, alat pengangkut dan kegiatan rumah tangga (Abdi \& Rahma, 2018). Karena pada dasarnya ada mesin atau pekerja dalam kegiatan di tempat tersebut yang menyebabkan munculnya kebisingan.

Lalu lintas jalan merupakan sumber utama kebisingan yang mengganggu sebagian besar masyarakat perkotaan. Salah satu 
sumber bising lalu lintas jalan antara lain berasal dari kendaraan bermotor, baik roda dua, tiga maupun roda empat, dengan sumber penyebab bising antara lain dari bunyi klakson saat kendaraan ingin mendahului atau minta jalan dan saat lampu lalu lintas tidak berfungsi (Malau et al., 2017).

Dampak kebisingan akibat aktivitas transportasi dapat berupa gangguan penurunan kualitas lingkungan hidup yang dialami oleh permukiman di sepanjang tepi jalan dan pengguna jalan. Dalam jangka waktu pendek efek gangguan ini tidak akan berpengaruh bagi fisiologis manusia yakni fungsi pendengaran. Namun dalam jangka waktu lama akan menimbulkan menurunnya fungsi dari pendengaran serta gangguan berupa psikologis penduduk yang tinggal di kawasan tersebut, seperti mudah marah atau susah tidur (Satoto, 2018).

Seperti halnya aktivitas pada lalu lintas, untuk pemukiman sekitar jalur Kereta Rel Listrik (KRL). Pada tahun 2020 telah dilakukan penelitian untuk pemukiman di sekitar stasiun KRL Tebet dengan jarak di sekitar 20 meter dari sumber kebisingan sebesar 80,5 dBA (Wati, 2020). Sedangkan berdasarkan Kepmen LH No. 48 tahun 1996 Nilai Ambang Batas (NAB) yang diizinkan yakni $55 \mathrm{dBA}$.

Kebisingan dapat diukur dengan menggunakan alat sound level meter. Alat ini mengukur intensitas atau kekerasan suara dalam satuan hertz dan gelombang suara dalam satuan decibel. Telinga manusia hanya mampu menangkap intensitas suara berkisar antara 20 - 20.000 hertz dan dengan batas aman frekuensi suara sekitar 85 decibel. Tekanan terhadap suara atau bunyi yang melampaui batas aman dalam waktu yang lama dapat menyebabkan terjadinya ketulian sementara atau permanen (Tanoga \& Adi, 2016)

Alat yang sudah ada yang digunakan untuk mengukur intensitas bunyi agar mengetahui berapa $\mathrm{dB}$ yang ada pada area tersebut pada saat ini menggunakan alat berupa Sound Level Meter (SLM) yang banyak sekali tipe yang beredar di pasaran. Ada banyak sekali tipe SLM, seperti RION NL-27, Lutron SL-4012, Sanfix GM1351, Datalogger Pro Krisbow, dan masih banyak lagi yang lainnya. Selain SLM yang sudah ada di pasaran, ada juga yang menggunakan modul sensor seperti halnya modul sensor suara MAX4466 dapat dimanfaatkan sebagai alat pengukur tingkat kebisingan (sound level meter) dan aplikasi perangkat lunak (software) yang dirancang dapat menampilkan nilai intensitas bunyi (Anastasi et al., 2018)

Selain itu ada modul sensor suara KY037 yang bisa dijadikan untuk mengukur tingkat noise. Seperti halnya pengujian sensor suara dalam mengidentifikasi kerusakan motor pada pengujian keseluruhan sensor didapatkan hasil bahwa sensor suara dapat merespon suara atau noise yang dihasilkan oleh sampel motor yang kurang baik, hal ini juga dipengaruhi oleh perlakuan kalibrasi sensor sebelumnya dalam mengatur tingkat sensitifitas gangguan suara atau noise dari motor (Meidiasha et al., 2020).

Akan tetapi dari sekian banyaknya tipe yang ada di pasaran, belum ada yang multifungsi dengan memberikan rekomendasi material yang cocok untuk di beberapa area, khususnya dalam Neighborhood Noise, Transportation Noise, dan Industrial Noise.

Dengan adanya permasalahan tersebut, maka peneliti membuat sebuah alat yang tidak hanya digunakan untuk mengukur besar intensitas akan tetapi juga bisa digunakan untuk memberikan rekomendasi material. Rekomendasi material yang diberikan berdasar pada besar nilai suatu NRC atau SRC suatu material. Jadi dengan adanya hal tersebut merupakan suatu modifikasi dari SLM yang sudah ada, dengan harapan nantinya apabila ada masalah baik itu perseorangan ataupun perusahaan dalam kebisingan bisa menggunakan jasa dari alat dari peneliti yang tentunya lebih efisien untuk mengurangi kebisingan yang berada di sekitar sumber suara dan membuat orang-orang yang di sekitar sumber suara bisa lebih tenang dan tidak terkena dampak kebisingan tersebut.

\section{METODE/EKSPERIMEN}

Desain alat yang dibuat untuk melakukan dalam penelitian adalah seperti Gambar 1 : 


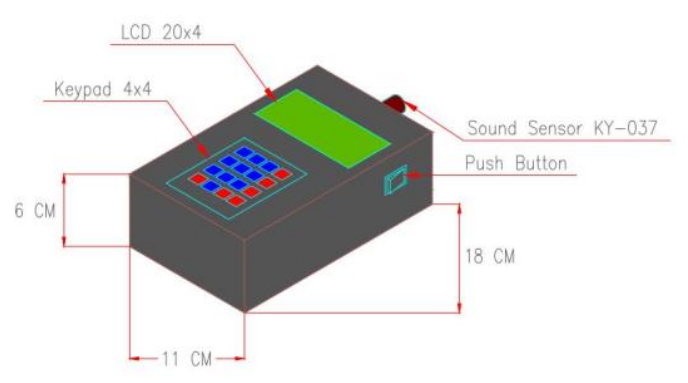

Gambar 1. Desain Alat

Penelitian dimulai dari perancangan alat yang kemudian semua bahan disusun menjadi alat dalam cover black box. Kemudian melakukan kalibrasi SLM AS804 dan adjustment sensor KY-037, dengan nilai SLM yang sudah direvisi tersebut. Kemudian dengan metode regresi sederhana digunakan untuk menentukan sejauh mana performa dari sensor KY-037 yang dibandingkan dengan nilai SLM AS804. Kemudian untuk material reduce bising dipilih melalui nilai NRC, STC dan loss factor. Penelitian dimulai dari bulan Maret 2020 hingga Juli 2020 dan dimulai dengan studi literatur Penelitian ini dilakukan dengan tahap-tahap sesuai diagram alir penelitian Gambar 2 di bawah ini :

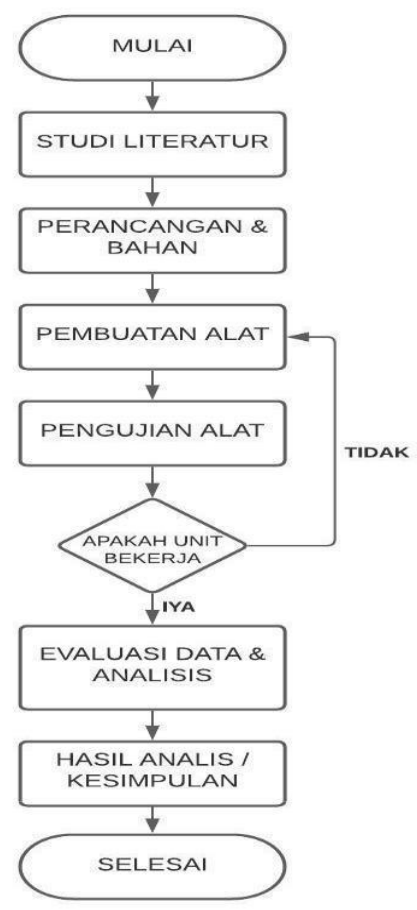

Gambar 2. Diagram Alir Penelitian
Persamaan gelombang bunyi disajikan dengan uraian penerapan hukum Hooke dan hukum Newton. Bunyi erat kaitannya dengan getaran, oleh karena itu bunyi hukum Hooke adalah jika gaya tarik yang diberikan pada sebuah pegas tidak melampaui batas elastis bahan maka pertambahan panjang pegas berbanding lurus atau sebanding dengan gaya tariknya.

Rumus Hukum Hooke:

$$
F=-k \cdot \Delta x
$$

Berdasarkan persamaan (1), di mana $F$ $=$ Gaya $(\mathrm{N}), k=$ Konstanta pegas $(\mathrm{N} / \mathrm{m})$ dan $\Delta x=$ Pertambahan panjang pegas $(\mathrm{m})$. Beberapa contoh dari Hukum Hooke yang diterapkan dalam kehidupan sehari-hari seperti jam yang memakai peer sebagai pengatur waktu. Contoh lain seperti ayunan pegas, teleskop dan lainlain

Dalam pengujian ini dilakukan di ruang akustik Laboratorium Teknik Fisika Universitas Nasional. Pengujian di ruang akustik dilakukan dengan tujuan untuk mengetahui karakteristik dari sensor KY-037 dengan tidak adanya noise atau suara dari luar ruangan yang masuk ke sensor itu sendiri, sehingga hanya sumber suara yang diujikan yang akan terukur pada sensor KY-037. Gambar dari ruang akustik dapat dilihat pada Gambar 3 di bawah ini :

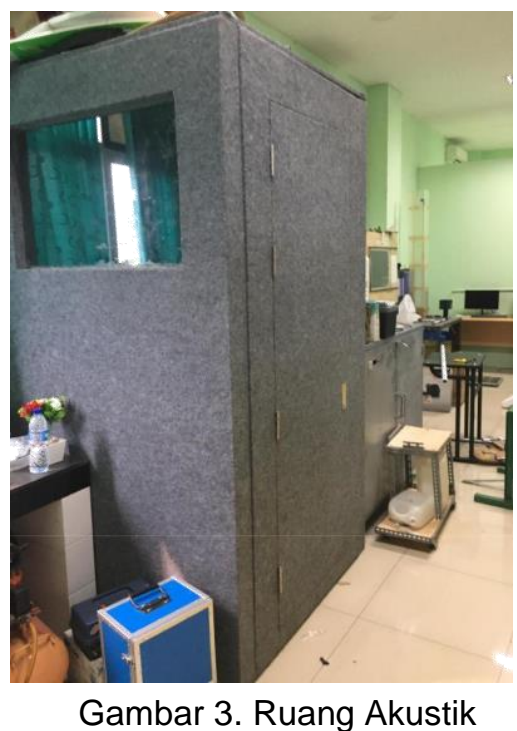

Pengambilan data dilakukan dengan dua metode yang berbeda. Metode yang pertama 
Rahmat Bagus Prasetya, Sunartoto Gunadi, dan Erna Kusuma Wati

adalah menggunakan standar SNI nomor 7231 tahun 2009. Metode pengukuran ini, dengan memposisikan alat ukur setinggi posisi telinga manusia yang ada di tempat kerja atau area yang terindikasi kebisingan. Arahkan mikrofon alat ukur dengan sumber bunyi sesuai dengan karakteristik mikrofon (mikrofon tegak lurus dengan sumber bunyi, $70^{\circ}-80^{\circ}$ terhadap sumber bunyi). Jarak titik pengukuran satu dan yang lainnya ditentukan sejauh 20 meter. Jarak 20 meter digunakan untuk mempermudah mengetahui jarak aman tingkat kebisingan dari sumber kebisingan. Kemudian posisikan tinggi SLM sejauh $120 \pm 10 \mathrm{~cm}$ dari permukaan tanah.

Dan metode yang kedua adalah metode pengukuran, perhitungan berdasarkan keputusan Menteri Negara Lingkungan Hidup nomor Kep-48/MENLH/11/1996. Berdasarkan metode ini dibagi menjadi 2 cara, yaitu cara sederhana dan cara langsung. Untuk cara sederhana dengan sebuah sound level meter biasa diukur pada tingkat tekanan bunyi $\mathrm{dB}(\mathrm{A})$ selama 10 (sepuluh) menit untuk tiap pengukuran. Pembacaan dilakukan setiap 5 (lima) detik. Sedangkan untuk cara langsung dengan sebuah integrating sound level meter yang mempunyai fasilitas pengukuran LTM5, yaitu Leq dengan waktu ukur setiap 5 detik, dilakukan pengukuran selama 10 (sepuluh) menit. Namun berhubung jam operasi KRL selama pandemi wabah covid-19 mengalami perubahan sehingga untuk kereta tujuan Bogor - Jakarta dan Jakarta - Bogor paling malam jam 22.00, maka untuk pengukuran malam tidak ada, maka dalam penelitian ini menggunakan cara sederhana.

Kemudian database material peredam kebisingan bisa dilihat pada Tabel 1. Kemudian material peredam kebisingan ini diambil dari nilai Noise Reduction Coefficient (NRC), Sound Transmission Coefficient (STC) dan juga Loss Factor.

Tabel 1. Material Peredam Kebisingan

\begin{tabular}{|c|c|c|}
\hline No & Analog Value & Nilai dB AS804 \\
\hline 1 & $<=62 \mathrm{~dB}$ & $\begin{array}{c}\text { Acourete Mat } \\
\text { Resin 2A }\end{array}$ \\
\hline 2 & $<=63 \mathrm{~dB}$ & $\begin{array}{c}\text { Acourete Noise } \\
\text { Curtain }\end{array}$ \\
\hline 3 & $<=68 \mathrm{~dB}$ & $\begin{array}{c}\text { Acourete Paint } \\
\text { EZ1 }\end{array}$ \\
\hline 4 & $<=69 \mathrm{~dB}$ & Acourete \\
\hline
\end{tabular}

\begin{tabular}{|c|c|c|}
\hline No & Analog Value & Nilai dB AS804 \\
\hline & & $\begin{array}{c}\text { Regufoam } \\
\text { Vibration } 150\end{array}$ \\
\hline 5 & $<=76 \mathrm{~dB}$ & $\begin{array}{c}\text { Acourete Fiber } \\
300\end{array}$ \\
\hline 6 & $<=80 \mathrm{~dB}$ & $\begin{array}{c}\text { Acourete } \\
\text { Perfowood - } \\
\text { Accoustic Panel } \\
881\end{array}$ \\
\hline 7 & $<=81 \mathrm{~dB}$ & $\begin{array}{c}\text { Acourete Board } \\
230\end{array}$ \\
\hline 8 & $<=82 \mathrm{~dB}$ & $\begin{array}{l}\text { Acourete } \\
\text { Diathonite }\end{array}$ \\
\hline 9 & $<=85 \mathrm{~dB}$ & $\begin{array}{l}\text { Accoustic } 15 \mathrm{~mm} \\
\text { Acourete } \\
\text { Diathonite } \\
\text { Accoustic } 20 \mathrm{~mm}\end{array}$ \\
\hline 10 & $<=87 \mathrm{~dB}$ & $\begin{array}{c}\text { Acourete } \\
\text { Diathonite } \\
\text { Accoustic } 30 \mathrm{~mm}\end{array}$ \\
\hline 11 & $<=89 \mathrm{~dB}$ & $\begin{array}{c}\text { Acourete Echo } \\
\text { Baffle }\end{array}$ \\
\hline 12 & $<=90 \mathrm{~dB}$ & $\begin{array}{c}\text { Acourete Fiber } \\
600\end{array}$ \\
\hline 13 & $<=91 \mathrm{~dB}$ & $\begin{array}{c}\text { Acourete } \\
\text { Perfowood - } \\
\text { Accoustic Panel } \\
16166\end{array}$ \\
\hline 14 & $<=92 \mathrm{~dB}$ & $\begin{array}{c}\text { Acourete } \\
\text { Diathonite } \\
\text { Accoustic } 40 \mathrm{~mm}\end{array}$ \\
\hline 15 & $<=94 \mathrm{~dB}$ & $\begin{array}{c}\text { Acourete Fiber } \\
800\end{array}$ \\
\hline 16 & $<=99 \mathrm{~dB}$ & $\begin{array}{c}\text { Acourete Fiber } \\
1000\end{array}$ \\
\hline 17 & $<=105 \mathrm{~dB}$ & $\begin{array}{c}\text { Soundstop tanpa } \\
\text { insulasi }\end{array}$ \\
\hline 18 & $<=111 \mathrm{~dB}$ & $\begin{array}{c}\text { Soundstop } \\
\text { dengan insulasi }\end{array}$ \\
\hline
\end{tabular}

Material dari peredam pada Tabel 1 adalah produk-produk yang dijual dipasaran yang sudah diuji besar nilai NRC, STC dan Loss Factor.

\section{HASIL DAN PEMBAHASAN}

Alat yang dibuat dalam penelitian ini dan yang digunakan dalam pengujian ini adalah seperti Gambar 4 di bawah ini :

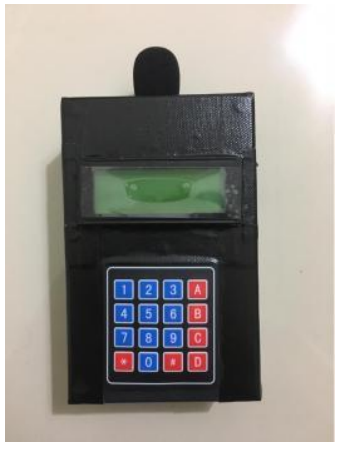

Gambar 4. Alat yang dibuat 


\section{Adjustment Sensor Suara KY-037}

Adjustment dilakukan untuk mengetahui performa dari sensor yang dipakai dengan SLM AS804 yang sudah terkalibrasi. Nilai sensor suara KY-037 dapat monitoring pada serial monitor pada Arduino. Kemudian nilai ini nanti yang akan digunakan untuk mengkonversi nilai dari sensor ke desibel.

Pengujian dilakukan dengan dua cara, yang pertama frekuensi yang sama dengan volume bunyi berbeda. Dan yang kedua adalah frekuensi yang berbeda dengan volume yang sama. Cara adjustment dapat dilihat pada Gambar 5 di bawah ini :

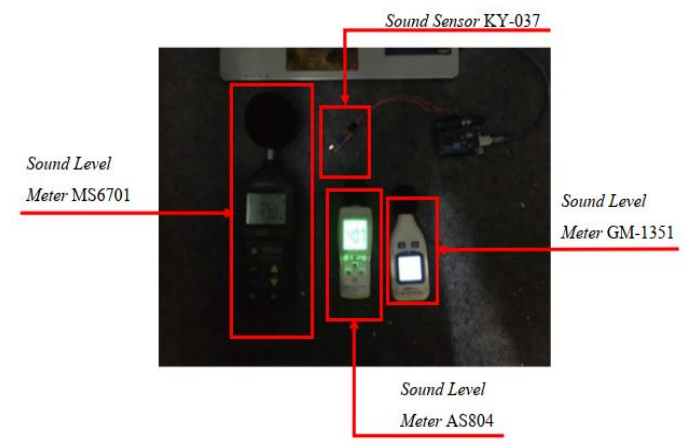

Gambar 5. Adjustment Sensor Suara KY-037

Selanjutnya pengujian pertama yang dilakukan adalah adjustment antara sensor KY037 dengan SLM AS804 dengan memberikan perlakuan sumber frekuensi yang berbeda dan sumber volume bunyi yang sama. Frekuensi diberikan mulai $80 \mathrm{~Hz}-10 \mathrm{KHz}$. Dari variasi frekuensi yang diberikan akan dibandingkan nilai desibel yang terdapat pada masingmasing alat ukur.

Tabel 2. Pengujian Pertama Adjustment

\begin{tabular}{ccc}
\multicolumn{3}{c}{ Sensor Suara KY-037 } \\
\hline $\begin{array}{c}\text { Frekuensi } \\
(\mathrm{Hz})\end{array}$ & $\begin{array}{c}\text { SLM AS804 } \\
(\mathrm{dB})\end{array}$ & $\begin{array}{c}\text { KY-037 } \\
(\mathrm{dB})\end{array}$ \\
\hline 80 & 64,7 & 64 \\
100 & 62,6 & 63 \\
120 & 59,6 & 61 \\
440 & 72,6 & 73 \\
880 & 82,8 & 84 \\
1000 & 80,7 & 81 \\
2000 & 85,6 & 88 \\
3000 & 78,7 & 79 \\
10000 & 69,2 & 68 \\
\hline
\end{tabular}

Kemudian untuk pengujian kedua yang dilakukan adalah adjustment antara sensor KY037 dengan SLM AS804 dengan memberikan perlakuan sumber frekuensi $1 \mathrm{KHz}$ dan sumber volume bunyi yang berbeda.

Tabel 3. Pengujian Kedua Adjustment Sensor Suara KY-037

\begin{tabular}{ccc}
\hline Volume & $\begin{array}{c}\text { SLM AS804 } \\
(\mathrm{dB})\end{array}$ & $\begin{array}{c}\text { KY-037 } \\
(\mathrm{dB})\end{array}$ \\
\hline 0 & 40,3 & 41 \\
10 & 64,5 & 65 \\
20 & 76,3 & 76 \\
30 & 81,4 & 82 \\
40 & 86,3 & 87 \\
50 & 89,5 & 90 \\
60 & 92,0 & 92 \\
70 & 92,4 & 92 \\
80 & 94,7 & 94 \\
90 & 96,5 & 96 \\
100 & 98,1 & 98 \\
\hline
\end{tabular}

Pada pengujian kedua ini dilakukan pada frekuensi yang sama yaitu $1 \mathrm{KHz}$. Karena pada pengujian pertama dalam frekuensi $1 \mathrm{KHz}$ mempunyai presentasi error yang paling kecil. Sehingga $1 \mathrm{KHz}$ yang dipilih.

\section{Konversi Analog ke Desibel}

Konversi analog ke desibel, dilakukan untuk mengetahui karakteristik dari sensor KY037. Kemudian dengan membandingkan nilai analog dengan nilai dB SLM AS804 menggunakan cara regression valve untuk menentukan nilai intercept dan slope. Pengujian dari perbandingan nilai sensor $\mathrm{KY}$ 037 dan SLM AS804 dapat dilihat pada Tabel 4 di bawah ini :

Tabel 4. Konversi Analog ke Desibel

\begin{tabular}{ccc}
\hline No & Analog Value & Nilai dB AS804 \\
\hline 1 & 430 & $42 \mathrm{~dB}$ \\
2 & 475 & $47 \mathrm{~dB}$ \\
3 & 498 & $58 \mathrm{~dB}$ \\
4 & 521 & $61 \mathrm{~dB}$ \\
5 & 557 & $63 \mathrm{~dB}$ \\
6 & 601 & $66 \mathrm{~dB}$ \\
7 & 619 & $70 \mathrm{~dB}$ \\
8 & 715 & $72 \mathrm{~dB}$ \\
9 & 920 & $81 \mathrm{~dB}$ \\
10 & 930 & $82 \mathrm{~dB}$ \\
\hline
\end{tabular}

Dari hasil tabel berikut dicari nilai slope dan intercept, guna mengetahui berapa konversi dari nilai sensor untuk menjadi $\mathrm{dB}$. Dengan menggunakan Microsoft Excel, maka diketahui jika, nilai slope 12,451 sedangkan untuk nilai intercept -172.756 . Kedua nilai ini yang nantinya akan dijadikan acuan untuk 
adjustment sensor suara KY-037.

\section{Pengujian di Musholla St. Pasar Minggu}

Pengujian ini dilakukan di musholla stasiun Pasar Minggu pada tanggal 18 Agustus 2020 yang dilakukan pengambilan dengan empat sampel waktu mulai LI sampai dengan L4. Pengujian dilakukan dengan 4 pengambilan data sampel pada hari yang sama. Sehingga bisa dibedakan antara L1 - L4. Hasil dari pengukuran untuk L1 dapat dilihat pada Tabel 5 - 8 di bawah ini:

Tabel 5. Pengujian di Musholla St. Pasar Minggu L1

\begin{tabular}{ccc}
\hline Jam & $\begin{array}{c}\text { Sensor KY-037 } \\
(\mathrm{dB})\end{array}$ & $\begin{array}{c}\text { SLM AS804 } \\
(\mathrm{dB})\end{array}$ \\
\hline 07.04 & 72,0 & 73,4 \\
07.05 & 73,2 & 75,2 \\
07.06 & 77,1 & 79,4 \\
07.07 & 66,3 & 67,1 \\
07.08 & 70,2 & 71,2 \\
07.09 & 79,7 & 80,0 \\
07.10 & 71,0 & 71,7 \\
07.11 & 70,5 & 72,0 \\
07.12 & 79,5 & 80,1 \\
07.13 & 73,4 & 72,9 \\
Rata-rata & 73,3 & 74,3 \\
\hline
\end{tabular}

Tabel 6. Pengujian di Musholla St. Pasar Minggu L2

\begin{tabular}{ccc}
\hline Jam & $\begin{array}{c}\text { Sensor KY-037 } \\
(\mathrm{dB})\end{array}$ & $\begin{array}{c}\text { SLM AS804 } \\
(\mathrm{dB})\end{array}$ \\
\hline 11.09 & 73,0 & 74,1 \\
11.10 & 64,9 & 68,6 \\
11.11 & 66,3 & 68,6 \\
11.12 & 73,8 & 74,2 \\
11.13 & 70,0 & 70,4 \\
11.14 & 70,4 & 71,2 \\
11.15 & 64,5 & 65,8 \\
11.16 & 68,5 & 68,8 \\
11.17 & 75,3 & 76,8 \\
11.18 & 65,9 & 67,1 \\
Rata-rata & 69,2 & 70,6 \\
\hline
\end{tabular}

Tabel 7. Pengujian di Musholla St. Pasar Minggu L3

\begin{tabular}{ccc}
\hline Jam & $\begin{array}{c}\text { Sensor KY-037 } \\
(\mathrm{dB})\end{array}$ & $\begin{array}{c}\text { SLM AS804 } \\
(\mathrm{dB})\end{array}$ \\
\hline 14.32 & 77,5 & 78,1 \\
14.33 & 64,0 & 65,7 \\
14.34 & 79,7 & 80,7 \\
14.35 & 64,2 & 65,4 \\
14.36 & 66,9 & 66,9 \\
14.37 & 79,1 & 78,3 \\
14,38 & 68,1 & 69,8 \\
14.39 & 69,8 & 70,3 \\
14.40 & 77,6 & 77,3 \\
14.41 & 70,0 & 70,7 \\
Rata-rata & 71,7 & 72,3 \\
\hline
\end{tabular}

Tabel 8. Pengujian di Musholla St. Pasar Minggu L4

\begin{tabular}{ccc}
\hline Jam & $\begin{array}{c}\text { Sensor KY-037 } \\
(\mathrm{dB})\end{array}$ & $\begin{array}{c}\text { SLM AS804 } \\
(\mathrm{dB})\end{array}$ \\
\hline 16.18 & 77,9 & 79,3 \\
16.19 & 81,0 & 81,1 \\
16.20 & 73,1 & 74,2 \\
16.21 & 75,8 & 77,8 \\
16.22 & 73,5 & 74,9 \\
16.23 & 82,3 & 84,5 \\
16.24 & 79,5 & 80,5 \\
16.25 & 73,5 & 74,2 \\
16.26 & 75,5 & 74,5 \\
16.27 & 76,3 & 76,3 \\
Rata-rata & 76,8 & 77,7 \\
\hline
\end{tabular}

Pengujian dilakukan di dalam musholla. Seperti yang kita tahu bahwa besarnya bising di area stasiun, dikarenakan lewatnya kereta, bisingnya orang mengobrol, serta suara dari operator untuk pengumuman. Akan tetapi karena untuk di setiap stasiun ada musholla tentunya bukan suatu halangan untuk mendapatkan suatu khidmat dalam beribadah. Oleh karena dengan pengukuran di area tersebut diharapkan nantinya dapat mengurangi bising sehingga bagi pekerja ataupun pengguna kereta bisa tetap aman dan bisa khidmat dalam beribadah.

Pengambilan data dilakukan dengan cara sederhana yaitu pengambilan data waktu setiap 10 menit dengan pembacaan nilai sensor setiap 5 detik. Jika mengikuti aturan dari pemerintah maka untuk melakukan pengukuran setidaknya menggunakan 4 sampel pada siang hari dan setidaknya 3 sampel pada malam hari, akan tetapi dikarenakan kebijakan baru dari pengelola baru $\mathrm{KRL}$, maka kereta hanya akan beroperasi sampai pukul 22.00. Sehingga untuk pengambilan data malam tidak bisa dilakukan. Dari keempat tabel di atas kita dapat melihat jika intensitas bising yang paling besar ada pada pengukuran pada L4. Ada banyak kemungkinan, yang pertama karena pada saat jam tersebut adalah jam untuk para pekerja yang pulang dari kantor dengan menggunakan KRL. Serta macetnya stasiun Pasar Minggu lalu adanya klakson motor bahkan orang berbicara juga termasuk di dalamnya yang menjadi penyebab bising pada L4 bisa lebih besar dibanding yang lainnya yaitu pada nilai 


\section{L1, L2 dan L3.}

Dari pengujian keseluruhan tersebut diambil rata-rata, sehingga dari sensor KY-037 rata-ratanya adalah $76,8 \mathrm{~dB}$ sedangkan sensor SLM 77,7 dB. Dan dari rekomendasi material berdasarkan tabel material peredam kebisingan adalah "Accourete Fiber 300".

\section{Pengujian di Masjid AT-Taqwa}

Pengujian ini dilakukan di Jalan Raya Pasar Minggu KM. 19.7, RT.002/RW.005, Pejaten Barat, Pasar Minggu, RT.2/RW.5, Pejaten Bar., Kec. Ps. Minggu, Kota Jakarta Selatan, Daerah Khusus Ibukota Jakarta 12520 pada tanggal 18 Agustus 2020 dan pengambilan data dilakukan menggunakan dua sampel yaitu L3 dan L4. Hasil pengujian dapat dilihat pada Tabel 9 dan 10 di bawah ini

\begin{tabular}{ccc}
\multicolumn{3}{c}{ Tabel 9. Pengujian di Masjid AT-Taqwa L3 } \\
\hline Jam & $\begin{array}{c}\text { Sensor KY-037 } \\
(\mathrm{dB})\end{array}$ & $\begin{array}{c}\text { SLM AS804 } \\
(\mathrm{dB})\end{array}$ \\
\hline 15.39 & 77,0 & 77,6 \\
15.40 & 74,8 & 75,9 \\
15.41 & 72,7 & 77,2 \\
15.42 & 78,7 & 78,8 \\
15.43 & 78,0 & 77,5 \\
15.44 & 74,7 & 78,1 \\
15.45 & 69,4 & 71,8 \\
15.46 & 75,7 & 77,4 \\
15.47 & 76,5 & 77,4 \\
15.48 & 73,5 & 74,0 \\
Rata-rata & 75,1 & 76,6 \\
\hline
\end{tabular}

Tabel 10. Pengujian di Masjid AT-Taqwa L4

\begin{tabular}{ccc}
\hline Jam & $\begin{array}{c}\text { Sensor KY-037 } \\
(\mathrm{dB})\end{array}$ & $\begin{array}{c}\text { SLM AS804 } \\
(\mathrm{dB})\end{array}$ \\
\hline 17.01 & 77,0 & 77,7 \\
17.02 & 77,0 & 78,3 \\
17.03 & 74,7 & 77,1 \\
17.04 & 76,2 & 77,2 \\
17.05 & 76,2 & 78,1 \\
17.06 & 77,3 & 76,8 \\
17.07 & 79,2 & 80,5 \\
17.08 & 78,6 & 78,3 \\
17.09 & 76,8 & 77,3 \\
17.10 & 78,1 & 76,4 \\
Rata-rata & 77,1 & 77,8 \\
\hline
\end{tabular}

Pengujian dilakukan ditempat tersebut dikarenakan area tersebut didekat jalan utama yang rame selalu dilewati oleh kendaraan dan tidak pernah sepi terutama pada saat pagi dan pulang kerja pada sore hari. Di samping itu seperti yang kita tahu tempat ibadah jika sesuai dengan aturan Kementerian Lingkungan Hidup, no : Kep-48/MENLH/11/1996, yang dianjurkan adalah $55 \mathrm{~dB}$. Sehingga hal ini perlu dilakukan tindakan agar bising pada area tersebut bisa tetap di bawah standar dari kementrian. Karena tempat ibadah tentunya merupakan tempat yang membutuhkan suatu keheningan serta khidmat dalam beribadah.

Pengambilan data dilakukan dengan cara sederhana yaitu pengambilan data waktu setiap 10 menit dengan pembacaan nilai sensor setiap 5 detik. Jika mengikuti aturan dari pemerintah maka untuk melakukan pengukuran setidaknya menggunakan 4 sampel pada siang hari dan setidaknya 3 sampel pada malam hari, akan tetapi dikarenakan kebijakan baru dari ta'mir masjid yang hanya membuka tempat ibadah disaat waktu akan menjalankan sholat. Oleh karena itu untuk jam yang bisa dilakukan adalah saat ashar (L3) dan mendekati mahgrib (L4). Dari kedua data tabel antara 3.5 dan 3.6 maka untuk bising yang paling besar ada pada waktu sampel L4 di mana sebesar 77,1 dB. . Ada beberapa kemungkinan kenapa pada saat waktu L4 intensitas bising lebih besar. Hal ini dikarenakan lebih banyaknya jumlah atau frekuensi dari kendaraan yang lewat karena pulang kerja disamping itu juga tetap dengan jadwal dari KRL yang juga memberikan sumbangsih dalam kebisingan di area sekitar.

Kemudian rekomendasi material yang disarankan oleh alat adalah Acourete Perfowood - Acoustic Panel. Karena di dalam pengujian untuk material tersebut mempunyai kemampuan NRC 0,44. Dan dari rekomendasi material berdasarkan tabel material peredam kebisingan adalah Acourete Perfowood Acoustic Panel 881.

\section{PEMBAHASAN}

\section{Pengujian di Musholla St. Pasar Minggu}

Pengujian di Mushola Stasiun Pasar Minggu dilakukan karena pertimbangan besarnya bising di area stasiun, lewatnya kereta, bisingnya orang mengobrol, serta suara dari operator untuk pengumuman. Akan tetapi karena untuk di setiap stasiun ada musholla tentunya bukan suatu halangan untuk mendapatkan suatu khidmat dalam beribadah. Oleh karena dengan pengukuran di area tersebut diharapkan nantinya dapat 
mengurangi bising sehingga bagi pekerja ataupun pengguna kereta bisa tetap aman dan bisa khidmat dalam beribadah.

Pengambilan data dilakukan dengan cara sederhana yaitu pengambilan data waktu setiap 10 menit dengan pembacaan nilai sensor setiap 5 detik. Jika mengikuti aturan dari pemerintah maka untuk melakukan pengukuran setidaknya menggunakan 4 sampel pada siang hari dan setidaknya 3 sampel pada malam hari, akan tetapi dikarenakan kebijakan baru dari pengelola baru $\mathrm{KRL}$, maka kereta hanya akan beroperasi sampai pukul 22.00. Sehingga untuk pengambilan data malam tidak bisa dilakukan. Dari keempat tabel di atas kita dapat melihat jika intensitas bising yang paling besar ada pada pengukuran pada L4. Ada banyak kemungkinan, yang pertama karena pada saat jam tersebut adalah jam untuk para pekerja yang pulang dari kantor dengan menggunakan KRL. Serta macetnya stasiun Pasar Minggu lalu bel motor hingga bahkan orang berbicara juga termasuk di dalamnya yang menjadi penyebab bising pada Tabel L4 bisa lebih besar dibanding yang lainnya.

Dari pengujian keseluruhan tersebut diambil rata-rata, sehingga dari sensor KY-037 rata-ratanya adalah $76,8 \mathrm{~dB}$ sedangkan sensor SLM 77,7 dB. Dan dari rekomendasi material berdasarkan tabel material peredam kebisingan adalah "Accourete Fiber 300" dengan NRC 0,375.

\section{Pengujian di Masjid AT-Taqwa}

Pengujian di Masjid At-Taqwa dengan pertimbangan bahwa ditempat tersebut dikarenakan area tersebut didekat jalan utama yang rame selalu dilewatin oleh kendaran dan tidak pernah sepi terutama pada saat pagi dan pulang kerja pada sore hari. Di samping itu seperti yang kita tahu tempat ibadah jika sesuai dengan aturan Kementrian Lingkungan Hidup, no : Kep-48/MENLH/11/1996, yang dianjurkan adalah $55 \mathrm{~dB}$. Sehingga hal ini perlu dilakukan tindakan agar bising pada area tersebut bisa tetap di bawah standar dari kementerian. Karena tempat ibadah tentunya merupakan tempat yang membutuhkan suatu keheningan serta khidmat dalam beribadah.
Pengambilan data dilakukan dengan cara sederhana yaitu pengambilan data waktu setiap 10 menit dengan pembacaan nilai sensor setiap 5 detik. Jika mengikuti aturan dari pemerintah maka untuk melakukan pengukuran setidaknya menggunakan 4 sampel pada siang hari dan setidaknya 3 sampel pada malam hari, akan tetapi dikarenakan kebijakan baru dari ta'mir masjid yang hanya membuka tempat ibadah disaat waktu akan menjalankan sholat. Oleh karena itu untuk jam yang bisa dilakukan adalah saat ashar (L3) dan mendekati mahgrib (L4). Dari kedua data tabel antara 3.5 dan 3.6 maka untuk bising yang paling besar ada pada waktu sampel L4 di mana sebesar 77,1 dB. . Ada beberapa kemungkinan kenapa pada saat waktu L4 intensitas bising lebih besar. Hal ini dikarenakan lebih banyaknya jumlah atau frekuensi dari kendaraan yang lewat karena pulang kerja di samping itu juga tetap dengan jadwal dari $K R L$ yang juga memberikan sumbangsih dalam kebisingan di area sekitar.

Kemudian rekomendasi material yang disarankan oleh alat adalah Acourete Perfowood - Acoustic Panel. Karena di dalam pengujian untuk material tersebut mempunyai kemampuan NRC 0,44. Dan dari rekomendasi material berdasarkan tabel material peredam kebisingan adalah Acourete Perfowood Acoustic Panel 881.

\section{PENUTUP}

Berdasarkan penelitian yang telah dilakukan, maka dapat disimpulkan bahwa hasil penelitian ini untuk pengujian di area masjid untuk sensor KY-037 yang terukur sebesar 79,1 dB sedangkan untuk SLM sebesar 79,7 dB. Kemudian untuk area musholla di stasiun Pasar Minggu untuk sensor KY-037 sebesar $77,1, \mathrm{~dB}$ sedangkan untuk SLM sebesar 77,8. Lalu rekomendasi material yang diberikan pada area masjid AT-Taqwa adalah Acourete Perfowood - Acoustic Panel 881. Kemudian untuk area musholla di stasiun Pasar Minggu adalah Accourete Fiber 300. Diharapkan pemilihan sensor untuk kedepannya bisa lebih baik lagi yang mempunyai sensitivitas yang lebih besar sehingga bisa lebih menyerupai 
64 | JIPFRI (Jurnal Inovasi Pendidikan Fisika dan Riset Ilmiah), Vol. 4 No. 2, November 2020

SLM sekaligus untuk ukuran bisa lebih kecil lagi.

\section{UCAPAN TERIMAKASIH}

Terima kasih saya ucapkan kepada dosen-dosen pembimbing di Universitas Nasional yang telah membantu saya dalam menyelesaikan penelitian ini.

\section{REREFENSI}

Abdi, A. W., \& Rahma, F. (2018). Tingkat Kebisingan Suara Transportasi Di Kota Banda Aceh. Jurnal Pendidikan Geografi, 18(1), 10-21.

Anastasi, L., Lapono, S., \& Pingak, R. K. (2018). Rancang Bangun Sound Level Meter Menggunakan Sensor Suara Berbasis Arduino Uno Design of Sound Level Meter Using Sound Sensor Based on Arduino Uno. Jurnal ILMU DASAR, Vol. 19 No. 2, Juli 2018:111-116, 19(2), 111-116.

Fithri, P., \& Annisa, I. Q. (2015). Analisis Intensitas Kebisingan Lingkungan Kerja pada Area Utilities Unit. Jurnal Sains, Teknologi Dan Industri, 12(2), 278-285.

Kementerian Negara Lingkungan Hidup. (1996). Keputusan Menteri Negara Lingkungan Hidup. Kep 48/MENLH/11/1996 tentang Baku Tingkat Kebisingan. Meteri Negara Lingkungan Hidup: Jakarta

Malau, N. D., Manao, G. R. S., \& Kewa, A. (2017). Analisa Tingkat Kebisingan Lalulintas di Jalan Raya. Jurnal Pendidikan, Matematika Dan Sains, 2(1), 89-98.

Meidiasha, D., Rif, M., \& Subekti, M. (2020). Alat Pengukur Getaran, Suara Dan Suhu Motor Induksi Tiga Fasa Sebagai Indikasi Kerusakan Motor Induksi Berbasis Arduino. Journal of Electrical and Vocational Education and Technology, 5(1), 366-370.

Satoto, H. F. (2018). Analisis Kebisingan Akibat Aktifitas Transportasi pada Kawasan Pemukiman Jalan Sutorejo-Mulyorejo Surabaya. Jurnal Teknik Industri
Heuristic, 15(1), 49-62.

SNI. (2009). Metode Pengukuran Tingkat Kebisingan di Tempat Kerja. SNI 7231: 2009. Jakarta: Badan Standarisasi Nasional

Tanoga, A. E., \& Adi, P. (2016). Analisis Tingkat Kebisingan Di Unit Utilities Pt Pertamina $\mathrm{Ru} \mathrm{Vi}$ Balongan. Jurnal Universitas Diponegoro.

Wati, E. K. (2020). PENGUKURAN DAN ANALISIS KEBISINGAN PERMUKIMAN TEPI REL KERETA LISTRIK Erna. STRING (Satuan Tulisan Riset Dan Inovasi Teknologi), 4(3). 